\title{
PENGUJIAN PEMBANGKIT LISTRIK TENAGA SURYA DENGAN POSISI PELAT PHOTOVOLTAIC HORIZONTAL
}

\author{
Sartono Putro \\ Jurusan Teknik Mesin Fakultas Teknik \\ Universitas Muhammadiyah Surakarta \\ Jl. A. Yani Kotak Pos 1 Pabelan Surakarta \\ sartono_putro@ums.ac.id
}

\begin{abstract}
ABSTRAK
Indonesia merupakan negara yang banyak memiliki pulau serta pegunungan, ada sejumlah daerah merupakan daerah terpencil yang tidak mendapatkan pasokan energi listrik PT PLN Persero. Untuk pemenuhan kebutuhan energi listrik di daerah tersebut dapat menggunakan sumber energi alternatif tenaga surya sebagai Pembangkit Listrik Tenaga Surya (PLTS). Penggunaan energi surya menjadi energi listrik menggunakan sel surya banyak dipengaruhi oleh kondisi lingkungan. Kegiatan ini bertujuan untuk mengetahui sejauh mana pengaruh lingkungan terhadap kinerja PLTS.

Photovoltaic yang digunakan dalam pengujian ini type 50-110-210 buatan PT. LEN Bandung. Pengujian PLTS dilakukan di Desa Ngiringin, Kecamatan Selogiri, Kabupaten Wonogiri dengan melakukan pengukuran terhadap kelembaban udara, temperatur, kecepatan angin, arah angin, arus dan tegangan keluaran sel surya. Pengkuran dilakukan pada pukul 07:00-17:00 WIB dengan selang waktu 20 menit.

Hasil pengujian PLTS didapatkan bahwa temperatur lingkungan berbanding lurus dengan arus listrik yang dihasilkan oleh sel surya, temperatur lingkungan berbanding terbalik dengan kelembaban udara. Sedangkan besarnya tegangan listrik yang dihasilkan oleh sel surya relatif stabil, untuk pengaruh kecepatan angin dalam pengujian ini tidak memiliki dampak terhadap kinerja sel surya. Daya listrik maksimal yang dihasilkan sel surya pukul 11:00-13:00 WIB memiliki prosentase rata-rata harian modul surya sebesar 50,94\%.
\end{abstract}

Kata Kunci: PLTS, Photovoltaic, Kelembaban Udara. Kecepatan Angin

\section{PENDAHULUAN}

Indonesia adalah negara yang banyak sekali memiliki pulau serta pegunungan, ada sejumlah daerah merupakan daerah terpencil yang tidak mendapat pasokan energi listrik PT PLN Persero. Untuk pemenuhan kebutuhan energi listrik di daerah tersebut dapatmenggunakan sumber energi alternatif tenaga surya sebagai Pembangkit Listrik Tenaga Surya (PLTS).
Photovoltaic (sel surya) merupakan piranti yang dapat mengkonversi cahaya matahari menjadi energi listrik. Energi surya adalah sumber energi yang dapat diperbaharui (renewable energi resources) yang sangat potensial. Energi surya dapat menghasilkan daya hingga 156.486 MW, jumlah yang lebih besar jika dibandingkan dengan sumber energi terbarukan yang lainnya. Indonesia merupakan negara yang terletak dalam jalur 
khatulistiwa yang sepanjang tahun mendapatkan cahaya matahari yang berlimpah.

Pemanfaatan energi surya sebagai PLTS sangat diminati dan mulai dikembangkan diseluruh pelosok negeri dengan melakukan banyak sekali penelitian serta pengujian. Ada beberapa hal yang perlu diperhatikan dalam pemanfaatan energi surya sebagai PLTS. Faktor-faktor yang mempengarui pengoptimalan energi surya menjadi energi listrik yaitu: pengaruh cuaca, kelembaban, temperatur, posisi sel surya serta arah angin yang terdapat pada permukaan sel surya. Apabila ada yang menutupi lapisan luar sel surya, maka cahaya yang akan diterima oleh semi konduktor akan berkurang dan akan berimbas secara langsung terhadap proses konversi energi.

Penelitian mengenaii efektifitas sel surya terhadap perubahan kecepatan angin, kelembaban, temperatur dan arah angin sangat diperlukan. Hasil penelitian diharapkan didapatkannya referensi mengenai kemampuan sel surya dalam menghasilkan energi listrik.

\section{TINJAUAN PUSTAKA}

Rotib (2007), mengemukakan bahwa pemanfaatan energi cahaya matahari pada setiap zaman semakin meningkat seiring dengan pengetahuan yang kita dapatkan. Salah satu pemanfaatan energi cahaya matahari adalah Pembangkit Listrik Tenaga Surya (PLTS) yang memanfaatkan energi foton cahaya matahari menjadi energi listrik. Indonesia sendiri, sebuah negara yang dilewati oleh garis khatulistiwa dan menerima panas matahari yang lebih banyak daripada negara lain, mempunyai potensi yang sangat besar untuk mengembangkan pembangkit listrik tenaga surya sebagai alternatif batubara dan diesel sebagai pengganti bahan bakar fosil, yang bersih, tidak berpolusi, aman dan persediaannya tidak terbatas.

Adapun prinsip kerja sel surya dijelaskan oleh Sungkar (2006), bahwa sel surya (photovoltaic cell) bekerja dengan menangkap sinar matahari oleh sel-sel semikonduktor untuk diubah menjadi energi listrik. Sel-sel ini termuat dalam panel-panel yang ukurannya dapat disesuaikan dengan keperluannya, apakah untuk rumah tangga, perkantoran atau pembangkit listrik sekala besar. Hal yang sama dikemukakan oleh Rhazio (2007), bahwa sel surya merupakan komponen vital yang terbuat dari bahan semikonduktor yang dapat mengkonversi energi surya menjadi arus listrik DC.

Sementara itu Yushardi (2002), menjelaskan bahwa pada pagi hari pukul 6.00 WIB tingkat kelembaban besar yaitu 88\% dan terjadi pengembunan sambil menurunkan partikelpartikel padatan akibat polusi kendaraan bermotor dan industri ke permukaan bumi, sehingga pada saat ini kondisi atmosfir mempunyai kebeningan yang tinggi dan langit biru. Fenomena tersebut mengakibatkan pada pagi hari yang cerah pukul 9.00 WIB sel surya memiliki efisiensi terbesar yaitu dengan efisiensi $10 \%$. Pada siang hari partikel partikel padatan akibat pulusi kembali ke angkasa, dengan meningkatnya temperatur udara gerakan partikel semangkin hebat, sehingga meningkatkan hamburan radiasi surya yang masuk ke bumi. Hal ini mengakibatkan difusi ratio membesar dimana jumlah radiasi difusi lebih besar radiasi langsung, dan efisiensi sel surya pada pukul 12.00 WIB adalah sebesar 9\%, lebih rendah dari pada pagi hari. Pada sore hari akibat terjadi penguapan pada siang hari dan semakin meningkatnya partikel padatan polusi di udara, sehingga indek kecerahan terendah dimana tampak banyak awan. Selain itu radiasi surya global sangat kecil, sehingga pada sore hari sekitar pukul 17.00 WIB dengan efisiensi 3\%, kemampuan sel surya menurun secara drastis.

\section{Landasan Teori}

Pudjanarsa dan Nursuhud (2006), menyatakan, dengan mengambil sifat pancaran benda hitam suhu permukaan matahari dapat dihitung menggunakan rumus radiasi Stefan Boltzman:

$$
\begin{aligned}
& \text { Daya radiasi surya per } m^{2}=\sigma \times T_{m}^{4} \ldots \\
& \sigma=5,76 \times 10^{-80} \mathrm{~W} / \mathrm{m}^{2} \mathrm{~K}^{4} \\
& \text { Daya radiasi surya total }=4 \pi R_{m}^{4} \times \sigma T_{m}^{4} \\
& T_{m}=\left(R_{b m} / R_{m}\right)^{1 / 2} \times(S / \sigma)=5527^{\circ} \mathrm{C} \ldots \\
& \text { dengan, } \\
& R_{m}=\text { jari-jari matahari }
\end{aligned}
$$


$R_{b m}=$ jarak antara bumi matahari

$S$ = rapat radiasi matahari

Culp (1996), mengemukakan bahwa bumi bergerak mengelilingi matahari dalam suatu orbit yang berbentuk elips.

Waktu matahari rata-rata $=$

[waktu standar setempat + \{derajat timur

dari meridian standar $\times$ (4menit) $\}]$

Waktu surya nyata = Waktu matahari

rata-rata + persamaan waktu

Sudut-sudut penting dalam perhitungan energi suryameliputi:

1. Sudut garis lintang $L$

2. Sudut deklinasi ä

3. Sudut jam $\mathrm{H}$

Sudut-sudut diatas dapat dihitung sebagai berikut:

$$
\sin \hat{a}_{1}=\cos L \cos a ̈ \cos H+\sin L \sin a ̈
$$

$$
\sin a_{1}=
$$

Harga á ${ }_{1}$, â ${ }_{1}$ didapatkan dari tabel posisi matahari dan jumlah pancaran. Adapun intensitas radiasi normal langsung pada suatu hari yang jernih dapat ditaksir dengan persamaan:

$$
I_{\mathrm{DN}}=\mathrm{A} e^{-(\mathrm{B} / \mathrm{sin} \hat{\mathrm{a}})}
$$

dengan:

$A=$ Isolasi ekstraterestrial nyata

$B=$ Koefisien kepunahan atmosfer

Arus energi surya total pada permukaan bumi dari setiap orientasi dan kemiringan dengan sudut insiden adalah:

$$
I_{\mathrm{Tè}}=I_{\mathrm{DN}} \cos \mathrm{è}+I_{\mathrm{DS}}+I_{\mathrm{R}}
$$

dengan:

$I_{\text {DN }} \cos$ è $=$ komponen surya langsung

$I_{\mathrm{DS}} \quad=$ komponen difusi iradiasi surya
$I_{\mathrm{R}} \quad=$ radiasi gelombang pendek.

$I_{\mathrm{DS}}=C \times I_{D N} \times F_{S S}$

dengan:

$\mathrm{C}$ = Angka perbandingan antara difusi dengan radiasi surya langsung yang jatuh pada permukaan.

$F_{\mathrm{SS}}=\frac{1+\cos \beta_{2}}{2}$

Energi listrik yang dihasilkan modul surya:

$P=V \times I$

dengan:

$f \quad=$ effesiensi photovoltaic

$A=$ luas modul surya

$\cos \hat{a}=$ Sudut datang matahari terhadap bidang horizontal

$V \quad=$ tegangan listrik

$I \quad=$ arus listrik

\section{METODE PENELITIAN \\ Bahan dan Alat}

Bahan pemelitian adalah cahaya matahari untuk menguji kinerja sel surya dalam mengkonversi menjadi energi listrik yang dilakukan pada:

1. Lokasi: Dukuh Ngeringin No. 17 RT 02/VII Desa Keloron Wonogiri dengan letak goeografis $7,8^{\circ} \mathrm{LS}, 110,2^{\circ} \mathrm{BT}$.

2. Tanggal: 7-16 Desember 2007.

Alat penelitian meliputi:

1. Modul sel surya 50 Wp tipe 50-110-210.

2. Pengukur waktu, arloji.

3. Multimeter Sanwa DT-830B.

4. Amperemeter Heles CR-52.

5. Anemometer AM-4203.

6. Humidymeter. berikut:

Tahapan percobaan dilakukan sebagai

1. Pastikan semua instalasi PLTS terpasang dengan baik dan benar.

2. Pengukuran kelembaban udara

3. Pengukuran temperatur lingkungan. 


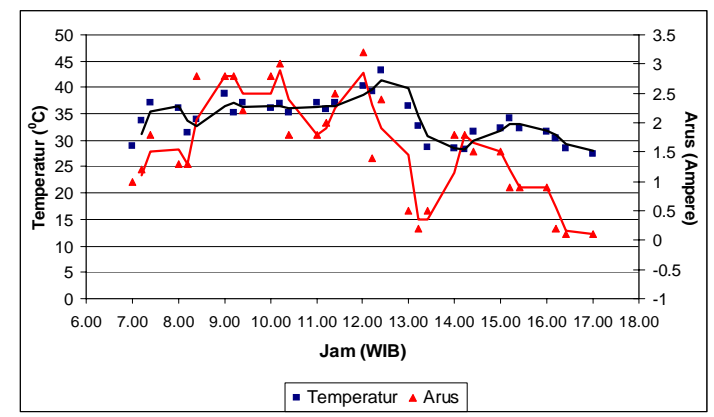

Gambar 8. Hubungan Tempeartur Terhadap Arus Listrik pada Pengujian III

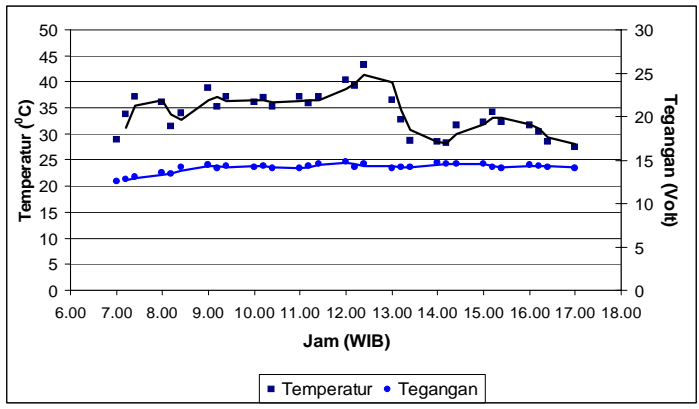

Gambar 9Hubungan Temperatur Terhadap Tegangan Listrik pada Pengujian III

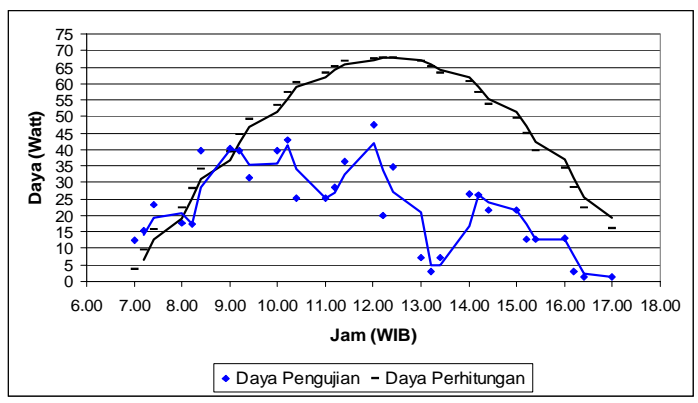

Gambar 10 Daya Hasil Pengujian dengan Daya Perhitungan Teoritis pada Pengujian III.

\section{Kondisi Hujan}

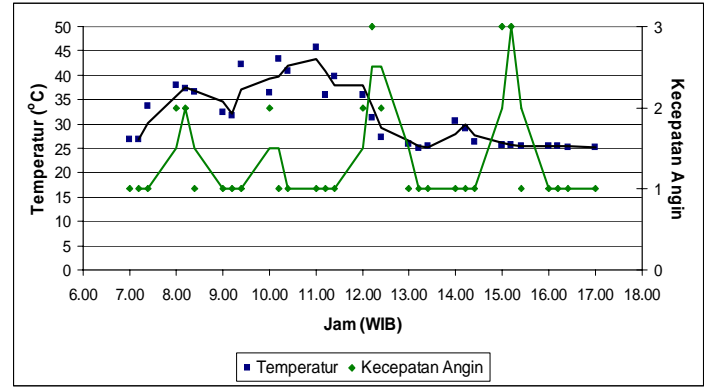

Gambar 11. Perubahan Temperatur dan Kecepatan Angin pada Pengujian V

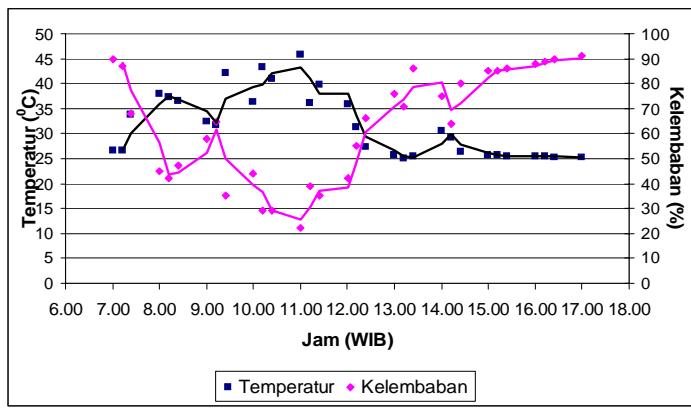

Gambar 12 Perubahan Temperatur dan Kelembaban pada Pengujian V

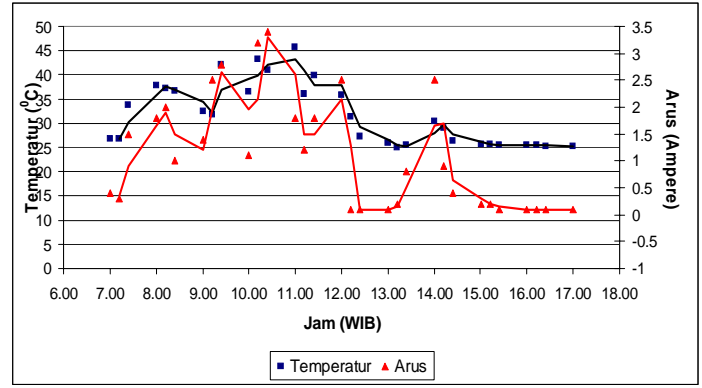

Gambar 13 Hubungan Tempeartur Terhadap Arus Listrik pada Pengujian V

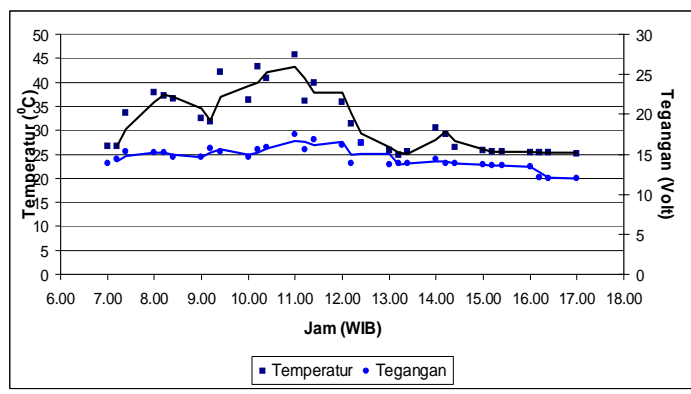

Gambar 14 Hubungan Temperatur Terhadap Tegangan Listrik pada Pengujian V

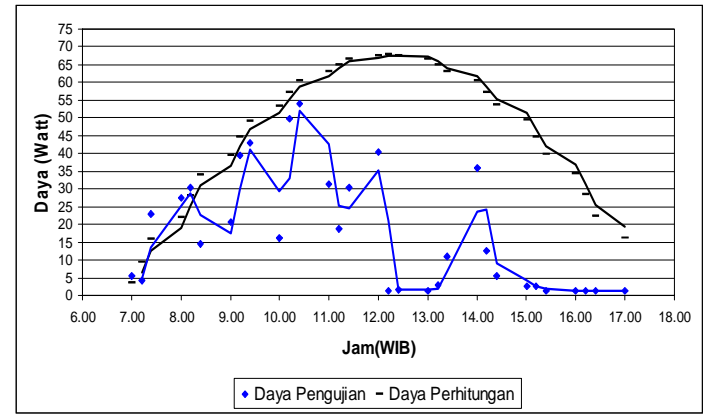

Gambar 15 Daya Hasil Pengujian dengan Daya Perhitungan Teoritis pada Pengujian V. 
Grafik hubungan kecepatan angin terhadap temperatur pada Gambar 1, Gambar 6, dan Gambar 11 menunjukkan bahwa pola kecepatan angin selama waktu pengujian tidak memiliki kesamaan. Adapun pola perubahan temperatur memiliki kesamaan yaitu memiliki puncak pada pukul 11.00 s.d. 13.00 WIB. Temperatur akan terus menurun setelah pukul 13.00 WIB. Fenomena ini sesuai dengan jarak antara surya dan bumi pada pukul 12.00 WIB memiliki jarak yang terpendek, sehingga energi radiasi surya yang diterima permukaan bumi besar. Hubungan kelembaban dengan temperatur yang ditunjukkan pada Gambar 2, Gambar 7 dan Gambar 12 menunjukkan hubungan berbanding terbalik. Pada kondisi temperatur rendah kelembaban tinggi sedangkan pada temperatur yang tinggi akan menguapkan kelembaban udara.

Gambar 3, Gambar 8, dan Gambar 13 menunjukkan bahwa besarnya arus listrik berbanding lurus dengan temperatur lingkungan. Kondisi ini terjadi pada cuara cerah, berawan dan hujan. Ini berarti temperatur lingkunganmerupakan faktor yang mempengaruhi keluaran arus listrik modul surya. Adapun tegangan listrik keluaran modul surya tidak dipengaruhi oleh kondisi lingkungan seperti ditunjukkan pada Gambar 4, Gambar 9, dan Gambar 14. Daya listrik yang merupakan perkalian tegangan dan arus hasil penelitian dan perhitungan teoritis menunjukkan kemampuan kinerja atau efisiensi modul surya.

\section{SIMPULAN}

Berdasarkan analisis yang dilakukan pada pembangkit listrik tenaga surya dengan posisi plat sel surya tipe 50-110-210 yang dipasang horizontal, maka dapat di ambil kesimpulan sebagai berikut:
1. Temperatur akan mempengaruhi kelembaban udara, semakin tinggi Temperatur udara maka kelembaban akan semakin rendah. Terlihat bahwa temperatur yang tinggi dengan kelembaban udara yang rendah akan menghasilkan arus listrik yang besar dan pada kelembaban yang tinggi pada temperatur yang rendah akan menghasilkan arus listrik yang rendah. Kecepatan angin dan arah angin tidak berpengaruh terhadap kinerja sel surya sedangkan hubungan antara kecepatan angin dan temperatur tidak berpengaruh terhadap kinerja sel surya.

2. Pada pengamatan yang dilakukan pada Pembangkit Listrik Tenaga Surya dengan posisi plat photovoltaic yang dipasang horizontal memiliki kestabilan dalam tegangan sedangkan arus yang dihasilkan modul surya relatif berubah-ubah. Arus terbesar yang di hasilkan Pembangkit Listrik Tenaga Surya (PLTS) ini didapatkan pada pukul 11.00-13.00 WIB dan hubungan antara daya hasil penelitian dan daya hasil perhitungan memiliki kecenderungan yang sama dengan prosentase rata-rata adalah sebesar 50,94\%. Dalam hal ini daya teoritis menggunakan asumsi langit cerah yang tidak terdapat partikel yang merefleksikan radiasi matahari serta tidak memperhitungan jenis sel surya yang digunakan sehingga terjadi perbedaan daya yang cukup besar dan pada dasarnya daya maksimal yang dapat dihasilkan sel surya sebesar 50 Watt.

\section{PERSANTUNAN}

Terimakasih kepada Bapak Agung Nur Muntaha, S.T. dan Saudara Amin Sholikin atas kerjasamanya dalam penelitian ini.

\section{DAFTAR PUSTAKA}

Culp. Jr, AW., 1991, Prinsip-Prinsip Kenversi Energi, Erlangga, Jakarta.

Pudjanarsa, A., Nursuhud, D., 2006, Mesin Konversi Energi, Penerbit Andi, Yogyakarta. 
Rhazio, 2007, Pembangkit Listrik Tenaga Surya, Institut Sains \& Teknologi, Jakarta. http:// rhazio.word press.com., maret 2008

Rotib, Widy, 2001. Aplikasi Sel Surya Sebagai Sumber Energi Alternatif; Dimensi Vol 4 No. 1 Juni 2001, Institute for Science and Technology Studies (ISTECS), Jepang. Diakses tanggal 20 september 2007 di istecs. http://istecs.org/Publication/Dimensi/dim_vol4no1_juni2001. pdf

Sungkar, R., 2007, Energi Surya. Diakses 20 September 2007 di Griya Asri. http://griya-asri.com/ index2.php?option=com_content\&do_pdf=1\&id=168

Yushardi, 2002, Pengaruh Faktor Metereologi Terhadap Pola Efisiensi Tiap Jam harian Pada Modul Sel Surya. Diakses tanggal 01-10-2007 di tumoutou. http://www.tumoutou.net/ 702_05123/yushardi.DOC 